\title{
RESEÑAS
}

\section{Leonardo GómEZ TORREGO: Las normas académicas: últimos cambios, Madrid, S/M 2011, 220 páginas. ISBN 978-84-675-4819-8}

\author{
Reseñado por Juan Carlos TORDERA YLLESCAS \\ I. E. S. Ausiàs March (Manises)
}

Cuando se habla de un investigador de la talla de Leonardo Gómez Torrego, ineludiblemente se hace referencia a la norma de la lengua española. Y buena muestra de lo dicho son las incontables obras existentes que no son sino un signo de la vitalidad y pujanza de nuestra lengua y la necesidad que alcanza, cada vez más, a un número creciente de personas de comunicarse con la lengua de Cervantes. Entre sus obras de carácter normativo, cabe citar obras tales como Manual de Español Correcto (en dos volúmenes en la editorial Arco/Libros) y sus posteriores actualizaciones Nuevo Manual de Español Correcto y Hablar y escribir correctamente; El léxico en el español actual: Uso y norma, Ejercicios de gramática normativa (ambos de la misma editorial) o libros tales como Ortografía del uso del español actual y Ortografía escolar (ambos en la editorial S/M). Por tanto, hablar de Gómez Torrego es hablar de una figura consagrada al buen uso de la lengua.

La obra a la que nos referimos aquí persigue, como bien ilustra su título, actualizar a los diferentes profesionales de la lengua, entre los cuales cita explícitamente a los profesores, partiendo de los recientes cambios normativos producidos a partir de la publicación del Diccionario panhispánico de dudas (en 2005), la Nueva Gramática de la Lengua Española en 2009 y de la Ortografía de la lengua española a finales de 2010. La normativa de una lengua es esa parcela que toda persona letrada cree conocer y con la que, sin embargo, siempre uno se lleva alguna inesperada (y, en ocasiones, comprometida) sorpresa ante lo que se creía que se podía decir o escribir y ante lo que realmente se debe producir. El objetivo de esta obra es, pues, registrar, organizar, comentar y, si fuere menester, criticar los últimos cambios normativos producidos en los últimos años. En suma, conocer, en su sentido más amplio, nuestra norma.

El libro, con un estilo indudablemente didáctico, hace cumplir la máxima de nuestro clásico Don Juan Manuel y expresa todo lo que quisiere con las menos palabras que pudiere. En un estilo próximo al aforismo, cada cuestión es abordada desde el estilo sucinto pero punzante y agudo que caracteriza las obras de este autor y por el que toda 
cuestión compleja es resuelta en un par de líneas y siempre acompañado de una justificada (y bien hallada) retahíla de ejemplos que permiten al lector visualizar rápidamente qué es aquello que es normativo y qué no lo es. Además, en cada cuestión, se señala de una forma tipográfica muy clara e ilustrativa, lo que ANTES era correcto y lo que AHORA lo es. Por este estilo didáctico, el autor incluye al final un índice temático que, sin lugar a dudas, es de extrema utilidad a la hora de realizar consultas puntuales.

Además, persigue organizar la ingente información normativa. En concreto, el libro está estructurado en cinco apartados, a saber, «Ortografía de las letras y de las palabras», «Acentuación», «Morfología», «Sintaxis»y «Léxico». En el apartado de «Ortografía de las letras y de las palabras», se abordan cuestiones tales como el nombre las letras (v. gr: ¿se debe decir y griega o ye?; ¿se debe decir be baja o uve?...), el uso de las grafías de origen extranjero ( $v$. gr.: se debe escribir show o chou), el uso de combinaciones gráficas no regulares en nuestra lengua ( $v$. $g r .:$ ¿se debe escribir psicólogo o sicólogo?), el uso de las mayúsculas (v. gr.: ¿se debe escribir el Presidente o el Presidente?)...

La sección dedicada a la acentuación será posiblemente una de las más recomendables y útiles a tenor de los importantes cambios realizados por la RAE recientemente. En los últimos años, ha sido una cuestión muy peliaguda la acentuación de los pronombres demostrativos así como el de adverbio solo y, por ello, el autor no duda en dedicarle una merecida atención a este problema. No menos problemática ha sido la acentuación de otras palabras usadas como monosilábicas en Hispanoamérica tales como guion y formas verbales tales como riais, frio, guiais... y, por ello, también se le dedica unos epígrafes descriptivos así como críticos.

En los dos siguientes apartados, «Morfología» y «Sintaxis», se tratan cuestiones de gramática normativa tales como el género de los sustantivos (v. gr.: ¿es correcto el uso hispanoamericano de palabras como el sartén, la tanga, la pus...?; ¿o es correcto decir una rehén en lugar de un rehén?), el plural de algunos sustantivos problemáticos (v. gr.: ¿cómo se hace el plural de los extranjerismos? ¿chándals o chándales, dosiers o dosieres, fans o fanes?; de otros sustantivos no menos problemáticos (v. gr.: tórax, tóraxs o toráxes?, ¿zulús o zulúes?, etc.), la nueva normativa respecto a construcciones sintácticas tales como $a+$ por + sustantivo ( $v$. gr.: Voy a por la pelota), sustantivo $+a+$ infinitivo (v. gr.: tema a tratar), la perífrasis (v. gr.: Deben (de) ser las cinco)...

Finalmente, en cuanto al léxico, se recogen las nuevas acepciones reconocidas por la RAE en palabras tales como deleznable, inédito, jugar, lapso, patología, tesitura, urgir, versátil, etc. Ofrece información sobre la corrección y/o adecuación de estos vocablos teniendo en cuenta la variabilidad no solo geográfica sino también la variabilidad de uso (o diafásica) de la lengua, por lo que, verdaderamente, podemos hablar de una normativa panhispánica.

Como se ha indicado, la función de la obra de Leonardo Gómez Torrego no es solo la de enumerar y estructurar los cambios realizados por la RAE, sino que, también, con espíritu crítico, los juzga. Así por ejemplo, el autor se cuestiona la idoneidad de no usar la mayúscula en el artículo ante el caso de nombres propios como el Teide, el 
Bierzo. Teniendo en cuenta que el nombre propio no necesita del artículo determinado, en los casos señalados, su presencia indicaría que el artículo es parte del nombre y, por tanto, debería ir en mayúscula. Igualmente, el autor afirma que si el hecho de no acentuar formas verbales como rio, frio... responde al hecho de respetar la norma hispanoamericana (que es la norma de la mayoría), no se entiende que no se recomiende la acentuación de palabras como huis, riais... cuando estas formas son propias de las regiones no voseantes $\mathrm{y}$, por tanto, mayoritariamente perteneciente a la norma peninsular.

En otros casos, a partir de la información aceptada por la RAE, el autor llega a completar información que no aparece explícitamente en las obras académicas. Por ejemplo, ante palabras como parasicología, el autor argumenta que también sería válida junto a parapsicología, teniendo en cuenta que se aceptan tanto psicología (forma recomendada) como sicología.

En conclusión, hemos de decir que esta obra muestra de una manera sencilla y clara los últimos cambios normativos sancionados por la RAE y se revela una obra sapientísima y recomendabilísima (que no «sabísima y recomendablísima») para los que, en su quehacer diario, la lengua se revela instrumento de trabajo como es el caso de profesores, maestros, logopedas, editores, correctores, traductores, escritores, periodistas... y para cualquiera que se interese por el correcto uso de nuestra lengua. 
